\title{
A piratical sabbatical
}

\section{It's just too good to be true.}

\section{Ian Whates}

You're good, you know that? Well yes, I do realize that's what you're paid to be.

No, really, I wasn't being a smart-ass... sorry. I just never realized it was going to be this realistic.

How it all started? At college; the usual vacation-time question: 'What do I do now?' Everybody's doing something; even my kid sister's gallivanting around the galaxy with her boyfriend. I wasn't going to sit around kicking my heels now, was I? Then I saw this ad on campus...

What? My parents? They're off on some pampered luxury cruise: auto-masseuse, stimulants-on-tap - the works.

Anyway, so I see this ad: Pirate Experience, the chance to be a buccaneer for a few weeks, how cool is that?

I took the virtual tour and I was hooked!

It was so well put together. We were all taken to this deserted corner of the old space port. Darkness, flickering lights — it already felt brimming over with skulduggery, even before we were in the air.

I didn't know any of the others, which was part of the adventure.

No, I didn't bother asking anyone. Pointless - I knew all my friends were fixed up already. I would have been too, if Marcy hadn't dumped me; the twofaced...

Okay, sorry. We boarded this rickety shuttle, and guess what they piped over the sound system as we took off? Old sea shanties: 'Yo-ho-ho and a bottle of rum' Stewards even came round with mugs of grog. It was all so authentic.

We docked with a larger craft waiting in orbit - The Queen Anne's Revenge. What kind of crazy name for a ship is that?

Sorry, haven't a clue. I'm not very good with ships... a frigate maybe?

Anyway, we boarded the Queen Anne and were each allocated a bunk - not hammocks thank goodness, but still pretty crude.

Oh, I'd say 25, maybe 30 of us. I never bothered counting.

We were divided into groups of four or five and given a rota of duties. One morning it would be minor patch work and repairs - there were plenty of those needed - the next it might be swabbing the decks... I kid you not. If that ship ever had autoclean, it had broken down long ago, or been switched off especially for our benefit.
The mornings were spent on chores, while the afternoons were reserved for more fun things: gunnery lessons in the simulator - I was particularly good at that - target practice with pistols in the ship's range, even sword-fighting and some hand-to-hand stuff. Never realized there was so much involved in being a

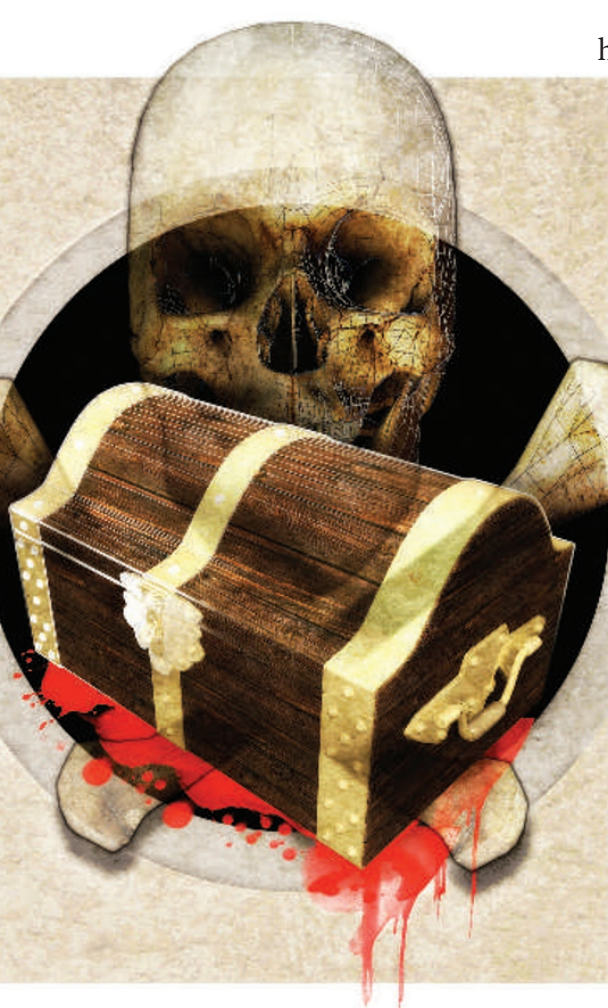

pirate, to be honest. It was exhausting but exhilarating.

In the evenings, after dinner, the lights would dim and we'd sit around a holofire sipping grog and bumboo from our black-jacks - that's a sort of cup - while members of the regular crew told tales of famous pirates and their exploits.

The crew were great; they had all the jargon and would roar at us to 'avast' and say 'ahoy' instead of hello, stuff like that. There was even the odd 'shiver me timbers'.

And then, to cap it all, they 'discovered' a ship - a big ocean liner, ripe for plundering. We knew what that meant: time for some real piracy. Sirens sounded and everyone ran around. I was assigned to gunnery, as I'd done so well on the simulators.

To be honest, the piracy bit wasn't as much fun as I'd hoped. It was mainly just waiting around. I wasn't involved in actually breaching the cruise-ship's hull - I hadn't done that well at the simulators, apparently — but was given the job of mopping up. So when two shuttles launched from the target after it had been breached, I shot them down.

Three shots, that's all it took, and I hit them both. Big explosions. Wham!

Of course I'm proud. It was some hot shooting and it's not as if anyone actually died, after all.

That's ridiculous. What reason would I have for really plundering an ocean liner?

Money? Come on, have you any idea how rich my parents are?

$\mathrm{Ha}$, ha, that's a good one - no, of course I'm not trying to bribe you.

Really, Officer, I'm not trying to bribe you.

After the raid? Well, the crew were in fine spirits - extra grog all round and lots of singing.

Next morning there were a few sore heads and dodgy stomachs, I can tell you. But instead of our chores we were given these two sealed chests...

Yes, the ones you found us with. We were put ashore at some backwater planet and told to wait, that someone would be along shortly to show us where to bury the treasure.

Well, we waited and waited, until you lot showed up and took us all into custody. I have to say, the way you came screaming down in that cruiser with all those flashing lights and gleaming insignia was quite something - very convincing. The most authentic part so far.

I realize you've done it many times before, that this is just another part of the Experience, but even so...

That's ridiculous. My folks are major wealthy. I've no motive for pulling something like this in the real world.

What do you mean 'inheritance'?

The ship we hit? I can't remember. If they told us the name, I missed it.

Golden Star? Sorry, means nothing to me.

My parents' cruise ship? Oh that's good, that's really good. You had me going there for a minute.

Lucky for me I know this is all part of the package. None of this is real, right?

Right?

During the past year, seven of lan's stories have appeared in various books and magazines, including Nature, the anthologies Glorifying Terrorism and BSFA-winning Time Pieces - which lan edited and published. 